УДК 634.10:581.47:581.19

\title{
АНТИОКСИДАНТНАЯ АКТИВНОСТЬ ПЛОДОВ РОДА MALUS В УСЛОВИЯХ ЮЖНОГО ПРЕДБАЙКАЛЬЯ
}

\author{
(ㄱ) М.А. Раченко", А.М. Шигарова, Е.И. Раченко \\ Сибирский институт физиологии и биохимии растений Сибирского \\ отделения Российской академии наук, ул. Лермонтова, 132, а/я 317, Иркутск, \\ 664033 (Россия), e-mail: bigmks73@rambler.ru
}

С помощью кинетической модели окисления $\beta$-каротина пероксидом водорода была дана оценка общей антиоксидантной активности водных и спиртовых экстрактов плодов 17 сортов яблонь, выращенных в условиях Южного Предбайкалья. Выделены сорта с высокими показателями антиоксидантной активности для использования в селекции. Ключевые слова: яблоня, сорта, антиоксидантная активность

\section{Введение}

Перед плодоводами стоят важные задачи по созданию новых сортов, обладающих высокой адаптивностью, устойчивостью к болезням и вредителям, урожайностью и регулярно плодоносящих. Особое внимание уделяется плодам, богатым питательными и биологически активными веществами, которые могли бы оказывать как профилактическое, так и лечебное влияние на организм человека.

В условиях усиливающегося экологического стресса, низкого качества продуктов питания, а также в результате перенесенных инфекционных заболеваний концентрация свободных радикалов в клетках организма человека может достигать уровня, при котором его собственная антиоксидантная система не справляется с деактивацией повреждающих агентов. Возникающий при этом «окислительный стресс» является одной из причин преждевременного старения организма, развития многих патологических состояний, в том числе онкологических и сердечно-сосудистых заболеваний [1].

Антиоксиданты относятся к классу биологически активных веществ, которые связывают излишние свободные радикалы, препятствуют ускоренному окислению липидов и образованию нежелательных продуктов окисления. Антиоксидантные системы включают в себя высокомолекулярные и низкомолекулярные вещества. К группе первых относят мембраносвязанные и цитозольные ферменты (супероксиддисмутаза, каталаза, глутатионзависимые пероксидазы и трансферазы). Низкомолекулярные антиоксиданты разделяют на жирорастворимые (токоферолы, каротиноиды, убихинон) и водорастворимые (аскорбиновая кислота, глутатион, тиоредоксин, билирубин и др.) [2]. Отдельной группой следует считать фенольные соединения. Большинство фенолов, содержащихся в плодах и ягодах, оказывают благоприятное действие на организм человека, что связано в основном с их антиоксидантными свойствами [3].

Природные антиоксиданты являются перспективными из-за их высоких пищевых и терапевтических

Раченко Максим Анатольевич - начальник опытной станции «Фитотрон», тел.: (3952) 42-59-03; факс: (3952) 51-07-54, e-mail: bigmks73@ rambler.ru Шигарова Анастасия Михайловна - ведущий инженер, кандидат биологических наук

Раченко Елена Ивановна - научный сотрудник, кандидат биологических наук эффектов, кроме того, фрукты, к которым относятся изученные плоды яблок, - возобновляемый источник БАВов. В связи с этим важнейшей задачей селекции является создание новых сортов яблонь с высоким содержанием витаминов, биологически активных веществ и других компонентов, необходимых для баланса полезных составляющих в питании, а также

\footnotetext{
*Автор, с которым следует вести переписку.
} 
выделение генисточников и доноров ценного биохимического состава для повышения эффективности селекционного процесса на базе изученных сортов, пригодных для выращивания в суровых условиях Южного Предбайкалья [4].

Цель работы - оценка общей антиоксидантной активности водно-этанольных экстрактов плодов яблони 17 сортов разного происхождения, выращенных в условиях Южного Предбайкалья, и выделение лучших генотипов для селекционного использования.

\section{Экспериментальная часть}

Объектом исследования послужили яблони разных селекционных станций и народной селекции: шесть сортов мелкоплодных полукультурок, пять сортов крупноплодных полукультурок, пять сортов культурных яблонь. Все исследования проводились в 2011-2012 гг. на базе Сибирского института физиологии и биохимии растений СО РАН, фермерских хозяйств Иркутского района Иркутской области.

Плодовые деревья выращивали в равных агротехнических и климатических условиях. В качестве подвоев использовали двухлетние сеянцы яблони ягодной (для стандартной прививки в низкий штамб). Все деревья культурных яблонь были сформированы в стелющейся форме. Плоды для анализа были собраны в состоянии потребительской зрелости, заморожены и хранились до анализа в холодильном шкафу при $-80{ }^{\circ} \mathrm{C}$.

Приготовление экстракта. 1 г измельченного сырья помещали в колбу, приливали 33 мл 80\%-го этанола (а для водной фракции 100 мл воды), с обратным холодильником нагревали на кипящей водяной в течение 45 мин. После фильтровали в мерную колбу вместимостью 100 мл. Экстракцию повторяли в тех же условиях еще 2 раза. Расчет 1 г сырья/100 мл 80\%-го этанола (или воды).

Измерение антиоксидантной активности (каротин- $\mathrm{H}_{2} \mathrm{O}_{2}$-модель). 2 мг $\beta$-каротина, 16 мг олеиновой кислоты и 160 мг Тритона X-100 растворяли в 50 мл хлороформа, после чего органический растворитель удаляли под вакуумом при $30{ }^{\circ} \mathrm{C}$. Остаток растворяли в бидистиллированной воде, раствор переносили в мерную колбу вместимостью 100 мл и доводили объем раствора до метки бидистиллированной водой. Для приготовления реакционной смеси в пробирку с пробкой со шлифом вносили 1,0 мл исследуемого раствора, 2 мл ДМСО, 2 мл раствора $\beta$-каротина и 2 мл 3\%-го раствора $\mathrm{H}_{2} \mathrm{O}_{2}$. Общий объем раствора доводили до 8 мл бидистиллированной водой. Полученную смесь термостатировали при $50{ }^{\circ} \mathrm{C}$ в течение 120 мин. Оптическую плотность исследуемого раствора определяли при 460 нм, используя в качестве раствора сравнения бидистиллированную воду. В качестве положительного контроля использовали реакционную смесь с ионолом (0,1 мг/10 мл). Величину антиоксидантной активности (\%) рассчитывали по формуле:

$$
A_{O x}=\left(1-\frac{D_{K}^{0}-D_{K}^{120}}{D_{S}^{0}-D_{S}^{120}}\right) \cdot 100
$$

где $\mathrm{D}_{\mathrm{K}}{ }^{0}, \mathrm{D}_{\mathrm{K}}{ }^{120}, \mathrm{D}_{\mathrm{S}}{ }^{0}, \mathrm{D}_{\mathrm{S}}{ }^{120}$ - оптические плотности контрольного и исследуемого растворов после 0 и 120 мин инкубации. Все измерения проводились в трех аналитических повторностях, рассчитано среднее значение и стандартное отклонение.

\section{Обсуждений результатов}

Плоды и ягоды содержат сотни разных антиоксидантов. Причем различия в их составе являются не только видоспецифичными, но и сортоспецифичными [5]. Это характерно для сибирских сортов яблонь, которые являются потомками не только культурных сортов, но и диких видов и форм [6]. Антиоксидантная активность экстрактов из плодов может быть обусловлена высоким содержанием в них водорастворимых антиоксидантов, таких как витамин C (аскорбиновая кислота) и жирорастворимых антиоксидантов, таких как витамины А, Е и др. Особую группу антиоксидантов образуют растительные флавоноиды, или Р-активные вещества, которые могут быть водорастворимыми (антоцианы, катехины и др.), спирторастворимыми (кверцетин) и жирорастворимыми. При этом все биологически активные вещества находятся в комплексе и усиливают действие друг друга [7-9].

В наших исследованиях мы определяли общую антиоксидантную активность (А товых экстрактах плодов яблонь. Для этого использовалась кинетическая модель окисления $\beta$-каротина пероксидом водорода в присутствии диметилсульфоксида (ДМСО). Механизм данной модельной системы 
заключается в том, что под влиянием $\mathrm{H}_{2} \mathrm{O}_{2}$ из ДМСО образуются перекисные соединения, которые вызывают деструкцию $\beta$-каротина, в результате чего снижается его концентрация в субстрате, и как следствие, падает оптическая плотность последнего. Данная система является широко используемой для моделирования процессов окисления [10].

Полученные результаты позволяют говорить о существенных различиях как внутри исследуемых групп, так и между группами.

Максимальная $\mathrm{A}_{\mathrm{Ox}}$ водных экстрактов из плодов мелкоплодных яблонь-полукультурок была обнаружена у сортов Красная гроздь (152\%), Красноярский снегирек (136\%) и Красноярский сеянец (147\%) (рис. 1). Максимальную А Ох показали спиртовые экстракты яблок сортов Красная гроздь (140\%), Красноярский снегирек (144\%) и Ранетка Ермолаева (139\%). У сорта Аленушка отмечена сравнительно низкая А тракт - 129\%, спиртовой - 123\%) несмотря на то, что у этого сорта достаточно высокий уровень витамина С (31 мг\%), количество Р-активных соединений невысоко (153 мг\%) [5, 11, 12]. Ранетка Ермолаева отличается высоким содержанием и аскорбиновой кислоты (38мг\%) и Р-активных веществ $(571$ мг\%) $[5,11]$ и имеет достаточно высокий уровень $\mathrm{A}_{\text {Oх }}$ (водный экстракт - 117 мг\%, спиртовой - 139мг\%).

У крупноплодных яблонь-полукультурок также была обнаружена разница в $\mathrm{A}_{\mathrm{Ox}}$ между сортами (рис. 2). У сорта Превосходное уровень $\mathrm{A}_{\mathrm{Ox}}$ в спиртовом экстракте на уровне максимальных значений мелкоплодных яблонь-полукультурок (145\%), а у сорта Подарок садоводам - самые низкие показатели среди яблонь-полукультурок (115\% в спиртовом экстракте).

Показатели $\mathrm{A}_{\mathrm{Ox}}$ водных экстрактов крупноплодных яблонь-полукультурок находятся в промежутке между 124 и 135\%. Исследованные сорта, как следует из литературных данных, имеют средние показатели содержания аскорбиновой кислоты (от 17 мг\% у Лады до 28 мг\% у Светлого) и Р-активных веществ (от 190 мг\% у Светлого до 340 мг\% у Лады) [6, 11].

Среди сортов культурных яблонь (рис. 3) максимальной А сорта Папировка (149\%) и водный экстракт плодов сорта Берканька (139\%). Эти показатели на уровне или выше таковых у яблонь-полукультурок. Для яблони сорта Антоновка обыкновенная и другими авторами показан низкий уровень антиоксидантной активности [5, 12]. По результатам наших исследований сорт Мелба не относится к группе сортов с высокой $\mathrm{A}_{\mathrm{Ox}}$, как это отмечено в других работах [12]. По данным Е.Н. Седова с соавт. [11], плоды Папировки, Антоновки обыкновенной и Мелбы не содержат высокой концентрации витамина С $(15,1,14,5$ и 11,2 мг\% соответственно), но богаты Р-активными веществами (259, 340 и 389 мг\% соответственно).

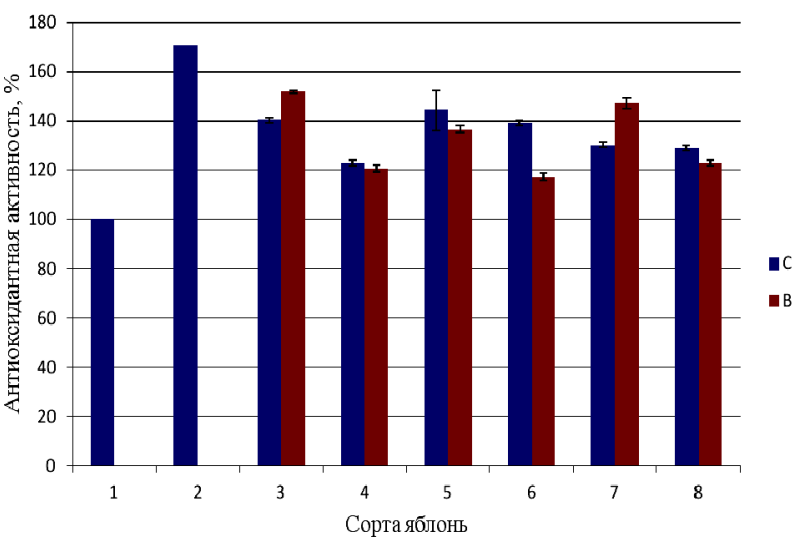

Рис. 1. Антиоксидантная активность спиртовых (C) и водных (В) экстрактов плодов мелкоплодных яблонь-полукультурок: 1 - контроль;

2 - положительный контроль (ионол); 3 - Красная гроздь; 4 - Фонарик; 5 - Красноярский снегирек; 6 - Ранетка Ермолаева; 7 - Красноярский сеянец; 8 - Аленушка

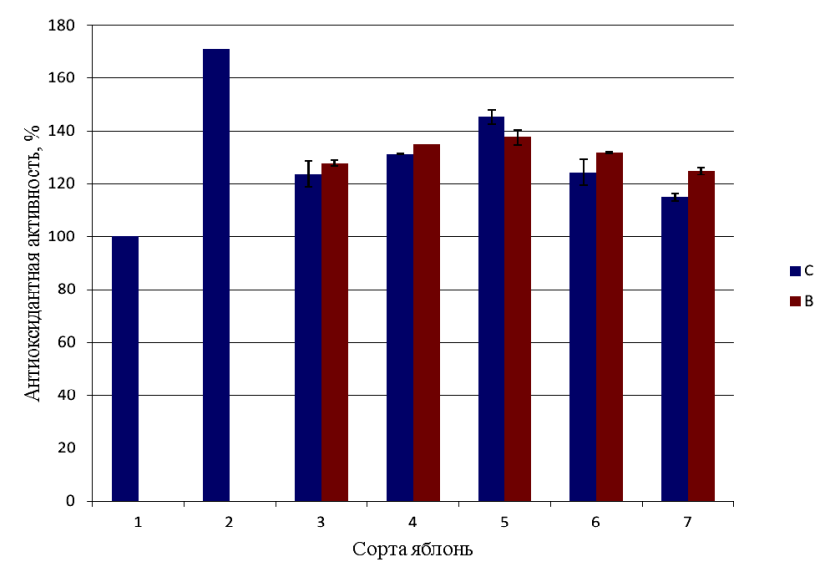

Рис. 2. Антиоксидантная активность спиртовых (C) и водных (В) экстрактов плодов крупноплодных яблонь-полукультурок: 1 - контроль; 2 - положительный контроль (ионол); 3 - Алтайское румяное; 4 - Лада; 5 - Превосходное; 6 - Светлое; 7 - Подарок садоводам 


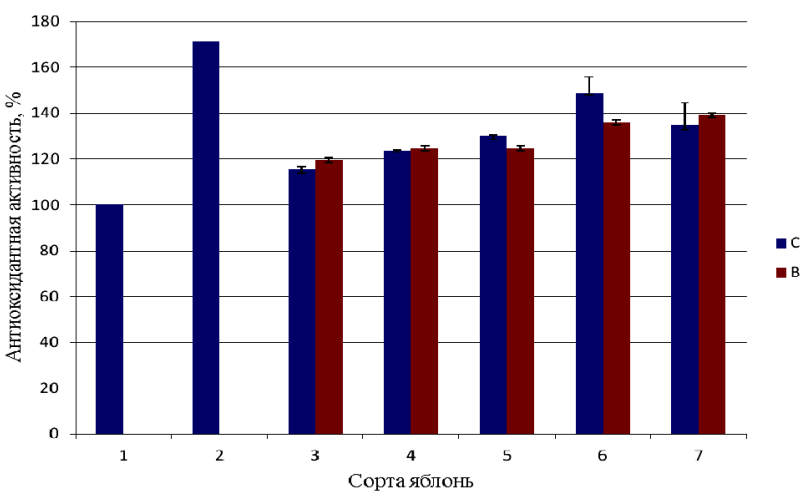

Рис. 3. Антиоксидантная активность спиртовых (С) и водных (В) экстрактов плодов культурных яблонь: 1 - контроль; 2 - положительный контроль (ионол); 3 - Антоновка; 4 - Мелба; 5 Боровинка; 6 - Папировка; 7 - Берканька

\section{Bbыводbl}

Наши исследования свидетельствуют о том, что в каждой группе сортов можно выделить высокие показатели $\mathrm{A}_{\text {Ox }}$, сопоставимые между собой: среди мелкоплодных яблонь-полукультурок это Красная гроздь и Красноярский сеянец, среди крупноплодных яблонь-полукультурок - Превосходное, среди культурных яблонь - Папировка и Берканька. Эти сорта являются наиболее перспективными для использования в селекции на высокое содержание биологически активных веществ. Можно предположить, что высокая $\mathrm{A}_{\mathrm{Ox}}$ связана с хорошей обеспеченностью плодов Р-активными веществами. Дальнейшие биохимические исследования позволят уточнить это предположение.

\section{Список литературы}

1. Меньщикова Е.Б., Зенков Н.К., Ланкин В.З., Бондарь И.А., Труфакин В.А. Окислительный стресс: Патологические состояния и заболевания. Новосибирск, 2008. 284 с.

2. Упадышев М.Т. Роль фенольных соединений в процессах жизнедеятельности садовых растений. М., 2008. 320 с.

3. Алехина С.П., Щербатюк Т.Г. Озонотерапия: клинические и экспериментальные аспекты. Саров, 2004. 244 с.

4. Раченко М.А., Раченко Е.И., Корзинников Ю.С. Изучение адаптированности сортов яблони в Предбайкалье // Вестник РАСХН. 2011. Вып. 4. С. 36-40.

5. Чупахина Н. Ю., Тынутаре Т., Моор У. Сравнение методов анализа суммарной антиоксидантной активности // Вестник Балтийского федерального университета им. И. Канта. 2012. Вып. 1. С. 69-74.

6. Помология. Сибирские сорта плодовых и ягодных культур XX столетия. Новосибирск, 2005. 568 с.

7. Потоцкая С.В., Лилишенцева А.Н., Павловская Л.М. Исследование содержания природных антиоксидантов в сырье и конфитюрах // Инновационные технологии в пищевой промышленности: матер. VIII междунар. науч.-практ. конф. Минск, 2009. С. 260-264.

8. Иващенко Н.И., Лилишенцева А.Н., Шрамченко О.В. Оценка вклада органических кислот в антиоксидантные свойства конфитюров // Пищевая промышленность: наука и технология. 2009. №3. С. 89-93.

9. Henriquez C., Almonacid S., Chiffelle I., Valenzuela T., Araya M., Cabezas L., Simpson R., Speisky H. Determination of antioxidant capacity, total phenolic content and mineral composition of different fruit tissue of five apple cultivars grown in chile // Chilean Journal of Agricultural Research. 2010. Vol. 70, N4. Pp. 523-536.

10. Оленников Д.Н., Танхаева Л.М., Агафонова С.В. Антиоксидантные компоненты плодовых тел Laetiporus sulphureus (Bull.: Fr.) Murr. // Прикладная биохимия и микробиология. 2011. Т. 47, №4. С. 1-7.

11. Седов Е.Н., Макаркина М.А., Левгерова Н.С. Биохимическая и технологическая характеристика плодов генофонда яблони. Орел, 2007. 312 с.

12. Савельев Н.И., Юшков А.Н., Акимов М.Ю., Борзых Н.В., Миронов А.М., Хожайнов А.В. Биохимический состав и антиоксидантная активность плодов яблони // Вестник Мичуринского государственного аграрного университета. 2010. №2. С. 12-15.

Поступило в редакизию 3 декабря 2012 2. 
Rachenko M.A. , Shigarova A.M., Rachenko E.I. THE ANTIOXIDANT ACTIVITY OF THE FRUIT IN THE GENUS MALUS IN SOUTHERN BAIKAL REGION

Siberian Institute of Plant Physiology and Biochemistry SB RAS, ul. Lermontova, 132, a/b 317, Irkutsk, 664033

(Russia),e-mail: bigmks73@rambler.ru

Using a kinetic model of oxidation of $\beta$-carotene by hydrogen peroxide was assessed the total antioxidant activity of water and alcoholic extracts of fruits 17 apple varieties grown in Southern Prebaikalia. It was marked varieties with high antioxidant activity for use in breeding.

Keywords: apple, variety, antioxidant activity.

\section{References}

1. Men'shchikova E.B., Zenkov N.K., Lankin V.Z., Bondar' I.A., Trufakin V.A. Okislitel'nyi stress: Patologicheskie sostoianiia i zabolevaniia. [Oxidative stress: Pathological conditions and diseases.]. Novosibirsk, 2008, 284 p. (in Russ.).

2. Upadyshev M.T. Rol' fenol'nykh soedinenii v protsessakh zhiznedeiatel'nosti sadovykh rastenii. [The role of phenolic compounds in the life processes of garden plants]. Moscow, 2008, 320 p. (in Russ.).

3. Alekhina S.P., Shcherbatiuk T.G. Ozonoterapiia: klinicheskie i eksperimental'nye aspekty. [Ozone Therapy: Clinical and experimental aspects]. Sarov, 2004, 244 p. (in Russ.).

4. Rachenko M.A., Rachenko E.I., Korzinnikov Iu.S. Vestnik RASKhN, 2011, no. 4, pp. 36-40. (in Russ.).

5. Chupakhina N. Iu., Tynutare T., Moor U. Vestnik Baltiiskogo federal'nogo universiteta im. I. Kanta, 2012, no. 1, pp. 69-74. (in Russ.).

6. Pomologiia. Sibirskie sorta plodovykh i iagodnykh kul'tur KhKh stoletiia [Pomology. Siberian varieties of fruits and berries of the twentieth century]. Novosibirsk, 2005, 568 p. (in Russ.).

7. Pototskaia S.V., Lilishentseva A.N., Pavlovskaia L.M. Innovatsionnye tekhnologii v pishchevoi promyshlennosti: mater. VIII mezhdunar. nauch.-prakt. konf. [Innovative technologies in the food industry: Materials VIII International Scientific and Practical Conference]. Minsk, 2009, pp. 260-264. (in Russ.).

8. Ivashchenko N.I., Lilishentseva A.N., Shramchenko O.V. Pishchevaia promyshlennost': nauka i tekhnologiia, 2009, no. 3, pp. 89-93. (in Russ.).

9. Henriquez C., Almonacid S., Chiffelle I., Valenzuela T., Araya M., Cabezas L., Simpson R., Speisky H. Chilean Journal of Agricultural Research, 2010, vol. 70, no. 4, pp. 523-536.

10. Olennikov D.N., Tankhaeva L.M., Agafonova S.V. Prikladnaia biokhimiia i mikrobiologiia, 2011, vol. 47, no. 4, pp. 1-7. (in Russ.).

11. Sedov E.N., Makarkina M.A., Levgerova N.S. Biokhimicheskaia i tekhnologicheskaia kharakteristika plodov genofonda iabloni. [Biochemical and technological characterization of the gene pool of apple fruit.]. Orel, 2007, 312 p. (in Russ.).

12. Savel'ev N.I., Iushkov A.N., Akimov M.Iu., Borzykh N.V., Mironov A.M., Khozhainov A.V. Vestnik Michurinskogo gosudarstvennogo agrarnogo universiteta, 2010, no. 2, pp. 12-15. (in Russ.).

Received December 3, 2012

Revised March 6, 2013

\footnotetext{
* Corresponding author.
} 
